\title{
scripted
}

Volume 16, Issue 1, August 2019

\section{The collective management of performers' rights in the UK: a story of competing interests}

\author{
Ananay Aguilar* \\ (ㄷ) (1) $(9)$ \\ (C) 2019 Ananay Aguilar \\ Licensed under a Creative Commons Attribution-NonCommercial- \\ NoDerivatives 4.0 International (CC BY-NC-ND 4.0) license
}

DOI: $10.2966 /$ scrip.160119.4

\begin{abstract}
In this article I examine the experience of UK performers using collective management organisation PPL, a UK CMO established by record companies that also manages the rights of performers. I consider the effect of the regulatory framework on the provision of transparency to PPL's performer members by drawing on primary sources including interviews with performers, PPL's regulation and its public-facing material. I demonstrate that PPL marshals social, financial, legal and technological resources to prioritise the interests of record companies over those of performers. Considering that the current legal framework supports PPL's actions, I discuss two alternatives: i) tightening regulation of individual CMOs whilst respecting their monopoly status, and ii) opening up the sector to competition. Despite difficulties faced by performers vis-à-vis PPL, I ultimately side with a large body of literature suggesting that performers are best off in an environment that supports CMO's monopoly status. However, in an environment where regulators resist tightening regulation, performers are forced to support a competitive market for CMOs.
\end{abstract}




\section{Keywords}

collective management organisations, CMOs, performers' rights, music copyright, PPL, EU Collective Rights Management Directive 2014

* Affiliated Researcher, Centre for Intellectual Property and Information Law (CIPIL), University of Cambridge, Cambridge, aa752@cam.ac.uk. The author wishes to gratefully acknowledge funding by the Leverhulme Trust and insightful commentary provided by John Williamson and two anonymous peer-reviewers. 


\section{Introduction}

Collective management organisations (CMOs) represent a key link in the life cycle of copyrights and related rights, including performers' rights. As Arnold explains succinctly, CMOs 'license the use of copyright works [and performances], monitor the extent of use by licensees, enforce the conditions of use by licensees, take action against infringers and collect and distribute royalties' ${ }^{1}$ Licensors are the rightholders who include publishers, record companies or musicians themselves, while licensees are the users of protected works and performances, such as large media corporations and large and small retail shops and service providers such as shops, hairdressers and restaurants. Their central role in the licensing of music has turned them into powerful intermediaries.

How $\mathrm{CMOs}$ are regulated is therefore an important part of how musicians and other rightsholders are remunerated. Regulation provides CMOs with standards regarding their governance, provision of services to users and accountability to their members: badly run CMOs lead to badly remunerated rights holders. Similarly, restrictive rules, or rules privileging one stakeholder group over others, will have direct consequences for the well-being of a jurisdictions' creative ecosystem. For instance, as I will describe in more detail below, CMOs may operate as a natural monopoly or within an environment where competition is fostered. Each of these scenarios has different consequences for the different stakeholders.

Research on CMOs continues to mostly address the theoretical foundations of these organisations, be it from a legal perspective ${ }^{2}$ or an economic

\footnotetext{
Richard Arnold, Performers' Rights, 5th ed. (London: Sweet \& Maxwell, 2015), para 3.69.

2 Ibid.; Adolf Dietz, "The European Commission's Proposal for a Directive on Collecting Societies and Cultural Diversity - a Missed Opportunity" (2014) 3 International Journal of
} 
one. ${ }^{3}$ Those concerned with the practical implications of the regulatory framework focus mainly on a CMO's governance structure ${ }^{4}$ and its users, ${ }^{5}$ less so on its members and the creative ecosystem surrounding it. In measuring the impact of the CMOs work on creativity, Street, Laing and Schroff have examined the CMOs' attitudes to and financial support of social and cultural causes. ${ }^{6}$ This approach provides a much-needed perspective of a CMO's political context. However, social and cultural concerns represent only a very small proportion of a CMO's operations (the stated salary at the time of writing for PPL's CEO tripled the amount of PPL's charitable donations ${ }^{7}$ ). More general questions on the

Music Business Research 7-25 available at

https://musicbusinessresearch.files.wordpress.com/2012/04/volume-3-no-1-april-

2014 dietz end1.pdf (accessed 2 August 2018); Daniel Gervais (ed.), Collective Management of Copyright and Related Rights, 2nd ed. (Alphen Aan Den Rijn: Kluwer Law International, 2010); Christoph Graber, "Collective Rights Management, Competition Policy and Cultural Diversity" (2012) 4 The WIPO Journal: Analysis of Intellectual Property Issues 35-42 available at http://www.wipo.int/publications/en/details.jsp?id=302\&plang=EN (accessed 2 August 2018).

3 Christian Handke and Ruth Towse, "Economics of Copyright Collecting Societies" (Social Science Research Network 2008) SSRN Scholarly Paper ID 1159085 available at https://papers.ssrn.com/abstract=1159085 (accessed 8 February 2018); Ariel Katz, “The Potential Demise of Another Natural Monopoly: Rethinking the Collective Administration of Performing Rights" (2005) 1 Journal of Competition Law \& Economics 541-593; Ariel Katz, "The Potential Demise of Another Natural Monopoly: New Technologies and the Administration of Performing Rights" (2006) 2 Journal of Competition Law \& Economics 245284.

4 Daniel Gervais, "Collective Management of Copyright: Theory and Practice in the Digital Age" in Daniel Gervais (ed.) Collective management of copyright and related rights (Aalphen Aan Den Rijn: Kluwer Law International, 2016); Reto Hilty and Sylvie Nérisson, "Collective Copyright Management" in Ruth Towse (ed.) Handbook on the Digital Creative Economy (Cheltenham: Edward Elgar Publishing Ltd, 2013); Morten Hviid, Simone Schroff and John Street, "Regulating Collective Management Organisations by Competition: An Incomplete Answer to the Licensing Problem?" (2017) 7 Journal of Intellectual Property, Information Technology and Electronic Commerce Law 256-270.

5 Gervais, supra n. 4.

6 John Street, Dave Laing and Simone Schroff, "Regulating for Creativity and Cultural Diversity: The Case of Collective Management Organisations and the Music Industry" [2018] 24(3) International Journal of Cultural Policy 368-386.

7 PPL, "Strategic Report for the Year Ended 31 December 2016" available at http://www.ppluk.com/About-Us/Who-We-Are/Annual-Reports/ (accessed 2 August 2018). 
political context and governance structure of a CMO combined with empirical work, can shed light on their impact on the creative ecosystem.

In this article, I will focus on the effect of the regulatory framework on the provision of transparency towards a CMO's members. Research for this article lies within a larger ethnographic project on performers' rights in the UK that provides a first critical examination of how these rights are used in practice. As such, the focus of this paper is on PPL (after its original long name Phonographic Performance Limited), a UK-based CMO set up by record companies to manage their rights but that has historically collected and distributed payments also for performers. I offer some of PPL's history to draw attention to its involved relationship with the UK's Musicians' Union (MU). I then turn to the current regulatory framework and use it as a backdrop to examine PPL's public and performer-facing material. Drawing on a diverse set of ethnographic and online material, I further examine the experience of using PPL by performers, especially session musicians. Considering that this experience is less than straightforward, I explore two well-documented alternatives for law reform: i) tightening regulation of individual $\mathrm{CMOs}$ whilst respecting their monopoly status and ii) opening up the sector to competition. Despite difficulties with PPL, literature suggests that there are good reasons for respecting the CMOs' monopoly status in the long term. However, EU regulators have opened the sector to competition, forcing performers to support a competitive market in order to make a living.

PPL has received scant attention from researchers. As I explain below, this may be partly because of the secrecy surrounding it. Another reason may be that performers' rights, especially their use and management, remain largely underresearched. Finally, comparatively speaking, the UK CMO of authors and publishers, the Performing Rights Society (PRS), has historically had a much higher turnover and thus a greater effect on the music ecosystem. This is reflected 
in greater media attention and its own history by Cyril Ehrlich. ${ }^{8}$ An important industry contribution to the PRS's practices is the Monopolies and Mergers Commission's (MMC) 1996 report "on the supply in the UK of services administering performing rights", on which I draw widely for contextual purposes. Other than this reference to PRS, comparative examination across CMOs or jurisdictions exceeds the remit of this article.

I was first made aware of the secrecy surrounding PPL when I began to make enquiries with colleagues who had themselves struggled to gain access to PPL data. I thus used the wider project on UK performers' rights to slowly garner the necessary evidence for this article. Building on 33 interviews I had conducted with performers in London between 2014 and 2016, I turned to what Ortner has called "interface ethnography", the study of data and events produced by a closed institution for "the public". ${ }^{9}$ I examined PPL's website, attended PPL and industry events, and signed up as a potential recipient of PPL payments. This gave me access to PPL's newsletter, workshops and, most importantly, its database. During this time, I learned about Les Hurdle's emails, a session musician who has taken it upon himself to police PPL's movements and make his colleagues aware of any developments. Access to 6-months-worth of email trails and a phone interview with the author, uncovered an additional small network of performers who felt aggrieved by PPL's actions. Finally, I also draw on commentary from a set of 15 interviews with high-level industry and government representatives which I conducted for an article on the reform of

8 Cyril Ehrlich, Harmonious Alliance: A History of the Performing Right Society (Oxford: OUP, 1989).

9 Sherry Ortner "Access: Reflections on Studying up in Hollywood" (2010) 11 Ethnography 211233. 
performers' rights. ${ }^{10}$ Initial concerns regarding the potential limitations of this study were in the end offset by the wealth of the evidence collected. As my research began to enter the public domain through academic talks, PPL opened up and I had the chance to visit its offices and meet high-level representatives. Two interviews with performer representatives resulted from this. Throughout the article, I will point to and give more detail about each of these pieces of evidence.

\section{PPL and Performers: A Long Partnership}

\subsection{From PPL's Early Years to the Implementation of the Rental Directive in the UK}

PPL was formed following a 1934 court case that awarded record companies the right to exploit the secondary use of recordings. ${ }^{11}$ In order to gain public legitimacy, PPL turned to the Musicians' Union. ${ }^{12}$ In 1946, PPL and the MU arrived at an arrangement that lasted over four decades and fed into debates about the later implementation of equitable remuneration rights. ${ }^{13}$ After the influential strike by the American Federation of Musicians between 1942-1944, the MU was in a good position to negotiate. PPL committed to pay 20 per cent of its net income to the record companies for featured artists and 12.5 per cent to the

10 Ananay Aguilar, “'We Want Artists to Be Fully and Fairly Paid for Their Work': Discourses on Fairness in the Neoliberal European Copyright Reform" (2018) 9 Journal of Intellectual Property, Information Technology and E-Commerce Law 160-178.

11 Gramophone Company Ltd v Stephen Cawardine \& Co. [1934] Ch. 450 (CH.D.) and PPL, "Company History - PPL" (PPL) available at http://ppluk.com/About-Us/Who-WeAre/Company-history/ (accessed 7 February 2018).

12 John Williamson, "For the Benefit of All Musicians? The Musicians' Union and Performers' Rights in the UK" in Andreas Rahmatian (ed.), Concepts of Music and Copyright: How Music Perceives Itself and How Copyright Perceives Music (Cheltenham: Edward Elgar Publishing Ltd, 2015).

13 Ibid., p. 178. 
MU on behalf of session musicians. The agreement also gave the MU control over the public performance of recorded music through restrictions placed by PPL on music users. Restrictions included provisions limiting the playing of records in a number of public spaces and the controversial "needletime", a restraint on the broadcasting of recorded-rather than live-music measured in hours. ${ }^{14}$ Together, the session musician's fund and restrictions allowed the MU to better control musicians' live work by ensuring that it was not fully replaced by recordings.

The agreement reached an end towards the last quarter of the century when the growing broadcasting sector turned against "needletime" constraints, employment quotas and related policies imposed by the PPL-MU partnership. The broadcasters' efforts during Thatcher's pro-business government culminated in the referral of PPL to the Monopolies and Mergers Commission in 1988. The MMC's report on Collective Licensing legitimised PPL's ex-gratia payments to featured artists for broadcasting and public performance, but it had the effect of stripping the MU of its control over the sector. The MU also lost PPL as a strategic industry ally and its regular income for session work, which it used to fund its ‘Keep Music Live' Campaign. ${ }^{15}$

That same year, the Copyright, Designs and Patents Act 1988 (c 48) introduced civil rights of action to prevent the unauthorised exploitation of performances. However, the rights did not translate into economic benefits. The MU turned thus to lobbying activities. When in 1996 the Rental and Lending Rights Directive 92/100/EC was implemented in the UK, all performers were finally given the legal right to receive "equitable remuneration", where

\footnotetext{
$14 \quad$ Ibid., p. 179.

15 Ibid., p. 183.
} 
recordings of their performances were played in public or broadcast. ${ }^{16}$ This formalised previous informal arrangements between PPL and performers. ${ }^{17}$

The UK implementation of Article 8 of the Rental Directive, which itself implemented Article 12 of the Rome Convention, reflected this joint history. Unlike the Directive and Convention, in the UK performers were to receive remuneration from the record companies and not directly from the users. ${ }^{18}$ The relevant UK article reads like this: "the performer is entitled to equitable remuneration from the owner of the copyright in the sound recording". ${ }^{19}$ The UK wording thus places an unnecessary dependency of performers on record companies that forms the backdrop of the following discussion. With important precedents set in other European countries, record companies agreed then to pay performers 50 per cent of their revenue from public performance and broadcasting via PPL. ${ }^{20}$ How the relationship between performers and record companies via PPL unfolded is the focus of this article.

16 CDPA s. 182D.

17 During the following two decades performers saw other improvements to their rights: in 2006, under the Performances (Moral Rights etc.) Regulations implementing the 1996 WIPO Performers and Phonograms Treaty (Cm 3728), performers were granted moral rights. Finally, under the 2013 UK implementation of the Directive 2011/77/EU of the European Parliament and of the Council of 27 September 2011 amending Directive 2006/116/EC on the term of protection of copyright and certain related rights [2014] OJ L 265/1 (Copyright and Duration of Rights in Performances Regulations 2013 (S.I. 2013/1782)), performers were granted further concessions for works under copyright for more than 50 years (the so-called session fund, use-it-or-loose-it right and the clean slate right, see https://www.gov.uk/government/publications/copyright-in-sound-recordings/copyright-insound-recordings (accessed 25 March 2019).

18 Council Directive 92/100/EEC of 19 November 1992 on rental right and lending right and on certain rights related to copyright in the field of intellectual property [1992] OJ L 346/61, Art. 8 , and The Rome Convention for the Protection of Performers, Producers of Phonograms and Broadcasting Organisations 1961, Art. 12.

19 CDPA s.182D.

20 Richard Osborne, "Is Equitable Remuneration Equitable? Performers' Rights in the UK" (2017) 40 Popular Music and Society 573-591. 


\subsection{After the Implementation of the Rental Directive}

Foreseeing the implementation of this right, the MU together with Equity (the trade union of actors) formed the Performing Artists' Media Rights Association (PAMRA) to distribute the monies to performers and so remove the heavy administrative burden from the MU. But the transition towards the new system was complicated by the emergence of the rival Association of United Recording Artists (AURA). AURA's creation was instigated by the International Managers' Forum (IMF), which wanted to secure better terms for featured artists. As I explain elsewhere, featured artists are those who are featured on album sleeves and promotional material, who are either self-releasing artists or are signed by indie or major labels. In contrast, session musicians are hired on a one-off basis for live, recording, film or TV session work. Under current UK and EU copyright law, featured artists and session musicians fall both under the umbrella term 'performers', but in industry practice, they fulfil different roles and might represent different interests, as was the case in this debate. ${ }^{21}$

In what follows, I draw on personal interviews with Keith Harris, former PPL Performer Director, and John Smith, current PPL Chairman and President of the International Federation of Musicians, as well as former MU General Secretary. ${ }^{22}$ Harris and Smith coincided over PAMRA's struggles to distribute payments to its over 11,500 strong membership. AURA, with a much smaller membership and larger income was doing well until "serious irregularities" by one of its directors were discovered. ${ }^{23}$ These combined events forced the

21 Aguilar, "We want Artists to be Fully and Fairly Paid", supra n.10, pp. 169-70.

22 Ananay Aguilar, Interview with Keith Harris, "Interview with Keith Harris" (15 June 2017); Ananay Aguilar, Interview with John Smith, "Interview with John Smith" (5 November 2018).

23 Anita Singh, "Musicians Miss out as Radio Royalty Money Goes Missing from Accounts" (The Independent, 6 October 2004), p. 2. 
conversation between PAMRA, AURA and PPL regarding a merger. But unlike negotiations between PPL and the MU pre-1946, the MU, through PAMRA, was this time in a much weaker position. The merger was finally completed in 2006.

As part of the deal, PPL and performers agreed to create 4 places for performers on the PPL board, the performer directors. In addition, they created the role of Director of Performer Affairs. Keith Harris was appointed for the role, starting in November 2006. From 2015, Harris continued to serve as a consultant. Harris remembers finding "a lot of suspicion" between record companies and performers. This was reflected in simple day-to-day actions, such as referring to member record companies as "members", whilst member performers were called "performers". Harris addressed this by encouraging a more balanced terminology: "record company members" and "performer members". ${ }^{24}$

Although the enforcement of appropriate terminology has been used as an effective method to overcome differences in other contexts, here it was merely symbolic. As the current section 1.3 of the PPL Code of Conduct explains,

As a matter of company law, it is strictly speaking only PPL's recording rights holders that are "members" of PPL in the sense of being members of the company. However, insofar as it is possible and appropriate to do so, PPL treats performers registered with PPL as if they were "members" in this sense.

The code clarifies that performers registered with PPL are refused attendance or vote at PPL's annual general meeting (AGM), but instead "PPL has enshrined in its Articles of Association a commitment to hold an Annual Performer Meeting

24 Aguilar, Interview with Harris, supra n. 22. 
as an equivalent event for its performer members" ${ }^{25}$ In order to provide a safeguard for performers, PPL and the performer directors also agreed on the mediation roles of the "Performer Guardian Members". These are three performer representatives, two of which must be featured performers. According to Smith, proof of the smooth PPL-performer relations is that the Guardians have never been drawn upon.

The way in which these regulations are drafted today is the result of years of negotiation. When Fran Nevrkla became the new CEO of PPL in 2000, Smith recalls working closely with him on bringing the performers' organisations and PPL closer together: “This took around seven years of frequent, sometimes very bad tempered, meetings of what we called the Performer Forum".

Some more structural changes ensued: "the balance of the board has changed dramatically". ${ }^{26}$ As shown on the table, when Harris started at PPL in 2006, the total number of board members was 17, with much weight given to record companies. As Smith remembers, performers chose to side with the independent labels to gain more force. However, after the CRM Directive, the balance changed to better represent performers: at the time of the interview, the number of performers was being increased so that it would equal the sum of major and independent record company representatives. In addition to the main board, PPL also has a performer board, which discusses issues purely related to performers such as distribution methods, frequency of distribution and advanced payments and passes its decision to the main board for approval. ${ }^{27}$ According to Smith, these have until to date always been approved.

25 PPL, "PPL Code of Conduct for Members" s. 1.3, available at http://www.ppluk.com/Documents/Code\%20of\%20Conduct\%20PDFs/PPL\%20Code\%20of\% 20Conduct\%20for\%20Members.pdf (accessed 6 July 2018).

26 Aguilar, Interview with Harris, supra n. 22.

27 Ibid. 
PPL Directors Majors Independents Performers advisor

\begin{tabular}{llllll}
\hline 2006 & 4 & 4 & 4 & 4 & 1 \\
\hline 2018 & 3 & 3 & 3 & 6 & 1 \\
\hline
\end{tabular}

Harris admits that his approach may not have been "radical enough for some people and certainly not militant enough". ${ }^{28}$ Yet Harris and Smith agree that through years of "incremental" negotiation, ${ }^{29}$ they created an environment where collaboration between record companies and performers is encouraged and rewarded. Smith's position as Chair of the board demonstrates this. Below I discuss how this relationship is reflected in PPL's services towards performers.

It is worth highlighting here that the above debate assumes a homogeneity amongst performers that hides some important distinctions. As expressed earlier, performers are composed of a small number of highly successful featured artists and a vast majority of session musicians. While these two groups can be further subdivided and at the same time often merge into each other, this twoway distinction represents the most noticeable diversion of interests. As a general rule, session musicians (as well as most up-and-coming featured artists) sign standard contracts that entitle them to a lump sum for the service delivered and benefit in addition from the statutory right to equitable remuneration paid by PPL. The exact amount of the equitable remuneration depends on the success of the relevant work. In contrast, a small minority of highly successful featured artists are in a position to negotiate a sizeable advance and a royalty in contract

\footnotetext{
28 Ibid.

29 Aguilar, Interview with Smith, supra n. 22.
} 
in addition to the statutory equitable remuneration paid by PPL. Note that the equitable remuneration is divided amongst all of the performers in a work, with featured artists receiving the greatest share. The difference between the amounts received by session musicians and featured artists is significant. This difference is emphasised by complexities in the registration process of performers and their performances, as I explain below. This results in a divergence of interests in the two groups' relationship with PPL. ${ }^{30}$ As Kretschmer and Kawohl have observed and I have demonstrated elsewhere, the most successful artists tend to align their interests with those of the record companies who have invested in them. ${ }^{31}$

For the purposes of this discussion, this means that if the performers represented on the board are featured artists, the large majority of session musicians will struggle to have their interests represented equitably. For this reason, it is worth highlighting that the main stakeholders in debates surrounding PPL are three, not two, as is implied above, namely record companies, featured artists and session musicians. In this scenario, it will be argued that the interests of session musicians are the least well represented.

\section{The Regulatory Framework}

\subsection{The MMC 1996 on Performing Rights}

In separate developments also in 1996, members and users of the Performing

30 For differences in income earned from CMOs see Martin Kretschmer, "Artists' Earnings and Copyright: A Review of British and German Music Industry Data in the Context of Digital Technologies" (2005) 10 First Monday available at http://journals.uic.edu/ojs/index.php/fm/article/view/1200/1120 (accessed 2 July 2018).

31 Martin Kretschmer and Friedemann Kawohl, "The History and Philosophy of Copyright" in Simon Frith and Lee Marshall (eds.), Music and Copyright, $2^{\text {nd }}$ ed. (Edinburgh: Edinburgh University Press, 2004); Aguilar, "We Want Artists to Be Fully and Fairly Paid", supra n. 10. 
Rights Society (PRS) requested the MMC to review PRS's activities. ${ }^{32}$ The MMC found evidence of inefficiency, ${ }^{33}$ of lack of transparency ${ }^{34}$ and of unnecessary exclusivity practices. ${ }^{35}$ Importantly, the review highlighted the lack of standards amongst both domestic and international CMOs. ${ }^{36}$ The MMC therefore made recommendations regarding the governance structure, data management and accounting methods. It also offered guidelines on the creation of communication channels to provide information about internal procedures, consultative processes and a dispute resolution mechanism. ${ }^{37}$ In its wide perspective, the $\mathrm{MMC}^{\prime}$ s recommendations provide the gold standard for CMOs.

Importantly, the report also discussed the negative effects of too large corporate structures, especially in a monopoly situation such as that of PRS. Some characteristics highlighted were slow decision-making and lack of incentive to be the leader in the market, which would lead to the accumulation of inefficiencies ${ }^{38}$ and disregard for its members and clients. ${ }^{39}$ During the conservative pro-business government of this era, these characteristics were not balanced against the power of collectivities, such as the increased bargaining power in concentrated markets and the efficiencies gained in the complex running of collection and distribution mechanisms. Rather, the report expressed surprise at the finding that none of the stakeholders consulted were interested in setting up a competitor to PRS. ${ }^{40}$

32 Monopolies and Mergers Commission, "Performing Rights: A Report on the Supply in the UK of the Services of Administering Performing Rights and Fim Synchronization Rights" (1996) available at http://webarchive.nationalarchives.gov.uk/20111202164943/http://www.competitioncommission.org.uk/rep pub/reports/1996/378performing.htm (accessed 2 July 2018).

$33 \quad$ Ibid., para. 1.5.

$34 \quad$ Ibid., para. 1.6.

$35 \quad$ Ibid., para. 1.8.

36 Ibid., e.g. para. 3.36.

37 Ibid., paras. 2.115-27.

38 Ibid., para. 1.4-5.

$39 \quad$ Ibid., para. 1.6.

40 Ibid., para. 2.111. 
Crucially, the authors of the MMC report ignored global consensus captured only a year later in the Declaration of the UNESCO World Congress on the implementation of the Recommendation Concerning the Status of the Artist 1980 that

in the general interest, the collective administration of the rights of authors and performing artists and collective negotiation should be encouraged by regulation, without being subject to the law of competition or any other binding legislation. ${ }^{41}$

Like PRS's members, the 600 participants questioned contemporary methods of distribution and sampling 42 but considered unanimously that collective management "could not be deemed to be a 'market' in which there was a need to protect freedom of competition". ${ }^{43}$

Despite global consensus on the monopoly status of CMOs, less than 20 years later the EU regulation introduced competition into the $\mathrm{CMO}$ sector. On the introduction of this regulation, in 2016, PRS was released of its undertakings.

\subsection{The EU Collective Rights Management Directive 2014}

The first EU statutory instrument for CMOs was adopted in 2014: the Collective Rights Management Directive 2014/26/EU "on collective management of copyright and related rights and multi-territorial licensing of rights in musical

41 UNESCO, "Declaration of the World Congress on the Implementation of the Recommendation Concerning the Status of the Artists, CLT-97/CONF.206/CLD.10" available at http://unesdoc.unesco.org/images/0010/001090/109018e.pdf (accessed 5 July 2019), num. $38 \mathrm{~b}$.

42 International Federation of Musicians, "Conclusions of the World Congress on the Implementation of the Recommendation Concerning the Status of the Artist 16-20 June 1997 - UNESCO Headquarters", num. 21b.

43 Ibid., num. 20 and 21c. 
works for online use in the internal market", also known as the CRM Directive 2014. ${ }^{44}$ As the long title suggests, the Directive devotes one section on the collective management of copyrights and one on the multi-territorial licensing of rights in musical works for online use in the internal market.

The first section provides a solid framework for CMOs to work effectively on behalf of their members and avoid most of the mismanagement so clearly laid out by the MMC 1996 report. ${ }^{45}$ Regarding the governance structure, the Directive offers some degree of flexibility, but fails to ensure that all of the members have enough decision-making powers. In fact, it legitimises PPL's particular situation. As outlined above, PPL denies performers "company member" status and so performer representatives do not have voting rights at the AGM. ${ }^{46}$ In addition, current rules for general assemblies demand that all of the members' representatives are to be elected and not appointed. For performers this means that the place historically held by the MU at the Performer Board is now open to election. However, the changes in the number of representatives in recent years is a response to the requirement that the representation on the board be 'fair and balanced' ${ }^{47}$

Regarding transparency, the Directive's reporting measures give members tools to understand how their rights are being exploited and how much they are paying for the CMO's service. Note that the Directive does not demand CMOs to give details of revenues collected per user, which is the ultimate test of transparency. Commentary from fieldwork activities in industry meetings and

44 Directive 2014/26/EU of the European Parliament and of the Council of 26 February 2014 on collective management of copyright and related rights and multi-territorial licensing of rights in musical works for online use in the internal market [2014] OJ L 84/72.

45 Ibid., arts. 4-22.

46 PPL, "PPL Code of Conduct for Members", supra n. 25, s. 1.3.

47 Directive 2014/26/EU, arts. 8(11) and 9(2). 
events suggests that this requirement would threaten widely used nondisclosure agreements (NDAs) between contracting parties. It is believed that NDAs help to secure the best deal for each user without competitors learning about the details of each deal. In this way, legitimate price-differentiation amongst users can be ensured. This is preferred over the less convenient alternatives of anti-competitive price fixation or a simple lowering of prices across the sector through competition in the open market.

The second section on multi-territoriality exempts performers. As the title suggests, it addresses the licensing of rights in musical works, not performances, and those works for online use. Performers lack equitable remuneration rights for on-demand use (or, in legal terms, the "making available" of the performances they contributed to). ${ }^{48}$ However, this section may have some indirect effects, which I will discuss further below.

\subsection{The UK Collective Management of Copyright Regulations 2016}

The Collective Management of Copyright (EU Directive) Regulations 2016 (S.I. 2016/221) represents the UK implementation of the Directive. Although a broadly verbatim transposition of the Directive, it deviates from the text to offer additional measures to encourage competition. The Regulations do this by exempting micro-businesses of less than 10 employees and under $£ 2 \mathrm{~m}$ turnover from some of the regulations. ${ }^{49}$

The EU Directive leaves the creation of an alternative dispute resolution mechanism to the Member States. In the UK, arbitration of any dispute falls to the Secretary of State, who nominates the Copyright Tribunal to monitor the

48 CDPA s. $182 \mathrm{D}(1)$.

49 The Collective Management of Copyright (EU Directive) Regulations, SI 2016/221, e.g. regs 9, $15,31-2$. 
compliance with these regulations, but no solution is created to deal swiftly with individual cases. That said, I have identified at least one performer who successfully took PPL to the small claims court. ${ }^{50}$ This is a fast-paced, inexpensive mechanism for claiming sums of money owed. ${ }^{51}$

Another small but positive deviation regards the particular categories triggering a complaint. In the Directive these include complaints regarding the "authorisation to manage rights" and "membership terms". To these the UK has added the third broad category of complaints for "the service provided". 52

In short, the EU Directive is a stripped-down version of the MMC 1996 recommendations, which has the benefit of providing obligatory industry standards across existing and emerging CMOs in the large region of the EU. Regarding transparency, the Directive offers tools for potential members to make informed decisions about their $\mathrm{CMO}$ of choice but is less good at offering members decision-making powers and ensuring they know the amount due to them. The UK solution regarding an alternative dispute resolution procedure is onerous for individuals with low bargaining power, that is session musicians. For the licensing of musical works, the Directive (and its UK implementation) actively encourages the introduction of competition into the traditional monopoly system. In this regard, it ignores preceding documents such as the

50 “Musician Marcus O'Neil Wins Underpaid Royalties Case", BBC Radio 4 Today Programme (24 December 2014); Tall Order Records, "Indie Record Label Wins Groundbreaking Victory against Royalties Giant PPL" (Tall Order Records, 2014) available at http://tallorderrecords.com/ppl.html (accessed 6 May 2018).

51 "Make a Court Claim for Money" (GOV.UK) available at https://www.gov.uk/make-courtclaim-for-money (accessed 5 June 2018). See also research on the IP small claims court here: http://www.create.ac.uk/blog/2018/02/23/research-blog-series-assessing-ip-small-claims/ and advise on when to use it here: http://www.copyrightuser.org/understand/rightspermissions/enforcement/.

52 SI 2016/221, supra n. 51, reg. 31, para. 2(f). 
MMC 1996 and the 1997 UNESCO Declaration, in which unanimous support is given to CMOs' monopoly status.

\section{PPL's Interface Material}

So far I have outlined the involved history of PPL and the MU (section 2) and summarised the legal framework (section 3). In the following two sections (4 and 5), I draw on a wealth of material to present, first, the functioning of PPL, and, second, the perception of performers using PPL. In these sections, I stage my observations within the framework provided by Ewick and Silbey's everyday narrative on the law titled "with the law". ${ }^{53}$ In their book on everyday understandings of law, the authors found three central narratives: "before the law" describes perceptions of the law as intricate and remote, whilst "against the law" describes narratives in which the law is actively resisted. The relevant narrative here is "with the law", in which the law is "depicted as a game, a terrain for tactical encounters through which people marshal a variety of social resources to achieve strategic goals" ${ }^{54}$ In this set of narratives, people see themselves as bound by the law but also capable of changing it. As I described above, PPL was set up by record companies to collect and distribute monies for record companies. Under these circumstances, whilst also in charge of managing performers' rights, I argue that PPL's strategic goal is to marshal its resources to benefit record companies in the first place.

This section reports on the data collected during my time conducting "interface ethnography", the study of data and events produced by a closed

\footnotetext{
53 Patricia Ewick and Susan Silbey, The Common Place of Law: Stories from Everyday Life (Chicago: University of Chicago Press, 1998).

$54 \quad$ Ibid., p. 28.
} 
institution for "the public". ${ }^{55}$ It includes observations on PPL's website and industry events. By signing up as a potential recipient of PPL payments, I also gained access to PPL's newsletter, workshops and, most importantly, its database.

\subsection{The Website}

In order to assess the success of the website, I searched it following the standards demanded by the UK Collective Management of Copyright Regulations 2016. ${ }^{56}$ I focussed especially on regulations 20 and 21 regarding the disclosure of information to the public and the annual transparency report, those directed at transparency towards a CMO's current and potential members.

PPL complies with all the points in regulation 20. These demand, for example, that a CMO publishes its governance structure, statute and membership terms, and general policies regarding the management and distribution of monies. The code of conduct of members is easily searchable on the search bar by typing in "code of conduct", ${ }^{57}$ but also by scrolling down on any page to the bottom bar under "About us". The code of conduct itself has most of the information required and, where absent, the code provides live, up-to-date, links to the relevant information.

PPL's website also complies with the demands of regulation 21, regarding the annual transparency report. ${ }^{58}$ This regulation requires a detailed financial statement, specifying amounts collected and distributed, broken down by

55 Aguilar, supra n. 10.

56 SI 2016/221, supra n. 51.

57 PPL, "PPL Code of Conduct for Members", supra n. 25.

58 PPL, "Phonographic Performance Limited (PPL) 2016 Transparency Report", available at http://www.ppluk.com/Documents/PPL\%20AGM/2017/Phonographic\%20Performance\%20L imited\%202016\%20Transparency\%20Report\%20-\%20FINAL\%20260417.pdf (accessed 2 July 2018). 
categories; statement of assets and liabilities; administration costs, including salaries of the top management team; investments in social, cultural and educational service and so on. To the extent of my accounting abilities, the financial statement observes all of the article's points and has been audited (as of last year) by a prestigious auditor. ${ }^{59}$ In short, PPL's website demonstrates full acknowledgement of the current regulation, in particular of those tools that allow prospective members to make informed decisions about the CMO.

\subsection{The Workshops}

During my fieldwork, I noticed a lack of external courses or workshops offered by PPL. Once I registered with PPL as a performer, I received emails offering me three to four "PPL in Session" workshops per year. The workshops are held in a large boardroom in PPL's offices in London's Soho, with very few exceptions across the rest of the country. The topics vary but are repeated over the years, including information on how to maximise international revenue, how to boost PPL income, on the membership benefits and on the specificities of classical music. The workshops are run by four to six PPL representatives from different departments, sometimes including board members, who present colourful slides giving plenty of information about PPL. The sessions include time to talk to instructors and fellow attendees over wine and food.

Unfortunately, the generously produced workshops were only sparsely attended. As a researcher, I enjoyed the environment, the level of detail about PPL's operations and the willingness to respond to questions related to the presentations. However, some fellow attendees were keen on resolving very detailed issues about their payments, which remained often unresolved. On one

59 PPL, "Strategic Report for the Year Ended 31 December 2016", supra n. 8. 
occasion, a musician wanted to understand why it took so long to get paid from recordings made abroad, when her colleagues, registered to other CMOs had received their income a long time ago. PPL explained its operations in great detail and offered a personalised session to see whether she was logged in properly (which she claimed she was), but a straightforward answer was not forthcoming. Nor, perhaps, was this the environment for these detailed cases. ${ }^{60}$ My experience of these workshops was thus that their reach and scope for attendants was limited.

During one session, however, I asked whether a PPL representative could come to my institution, where I was teaching a course on the music industry in the digital age. The response was positive. The instructor explained PPL's operations, thoroughly described the database and its functions, gave plenty of examples and answered difficult questions without hesitation. I have since recommended these workshops to colleagues.

\subsection{The Database}

The database is the core of PPL's business and the main interface with its registered members. The database holds all the information required to both license the music and to distribute collected licenses to PPL's members. It contains the metadata (or details included in the file) of all the music registered by PPL's members that is relevant to both identify a piece of music and determine its legal status. So, for example, the piece's metadata will contain an ISRC code (short for International Standard Recording Code, used to uniquely and permanently identify a piece of music) ${ }^{61}$ The metadata required by PPL will also

60 The type of unresolved questions that were posed, some more or less relevant to PPL's work, are exemplified in detail here: http://sadedrummer.blogspot.co.uk/?view=classic.

61 International ISRC Agency, "Home - International Standard Recording Code" available at http://isrc.ifpi.org/en/ (accessed 7 February 2018). 
contain information on the title, record company, country of recording, recording and publishing dates. Recording and publishing dates are important for determining the duration of copyright. According to the Copyright Act 1988, a recording's copyright expires 50 years after its recording date if it was never published, but 70 years from the publishing date, which can be any date within the 50 years of the recording date. ${ }^{2}$ Why these details are important will become clear below.

The metadata should ideally also include performer and/or contributor information. These are the details of all the people who contributed to the recording, be it featured artists (like conductors, soloists or named band members), non-featured artists hired to add texture to the music (including session and orchestral musicians) and/or any other contributors (such as sound engineers and audio producers) eligible for performers' rights. (To explain the technicalities of registration, I will henceforth group these performers and contributors under "performers", but will differentiate between featured artists and session musicians when there is a divergence in interests, processes, and/or outcomes.)

In order to get paid, a performer will need to be, firstly, registered with PPL and, secondly, logged in as a contributor to a recording. Note, however, that PPL denies performers registration of their own performances. PPL's database is filled by record companies, which provide all of their recordings' data. Once a record company logs in a sound recording with the correct performer line-up, the relevant performers will find the record listed in their personal statements.

Conversely, in a case where a record company incorrectly omitted a performer's contribution in a registration, the performer will struggle to find out

62 CDPA s. 191HA. 
about it. Indeed, the performer has no means of establishing whether the recording was registered or not, so must regularly trawl the database amongst the hundreds of thousands entries until the song has been registered (assuming the song bears the title the performer thought it would have when she contributed to it). In the event that performers find they have been omitted in a performer line-up of a registered recording, they are encouraged to make a claim. They can simply click the "Claim" button next to the recording's metadata and fill out the form linked to the relevant log.

The task of registering is burdensome and likely to introduce mistakes into the database. In this process, record companies are likely to privilege the correct registration of those few performers with whom they have employment contracts, that is, featured artists, over that of freelance session musicians. PPL, meanwhile, has two teams of about five people within its Member Services and Repertoire sections in charge of checking and cleaning the data, as well as attending to claims when the data is incomplete.

As I learned in the workshops, once PPL has collected all the revenue from licences and calculated what percentage of this revenue is due to whom (a topic for another article), PPL distributes the amounts to all of the individual bank accounts. Some money will be classed as non-distributable, because PPL lacks the relevant performer information or it is incorrect. PPL keeps these funds for six years, which is double the time required by law. ${ }^{63}$ Assuming PPL contacted some of the performers during the six-year period and paid them their monies due, PPL distributes the remainder of the fund to the recipients of the seventh year, in the proportions calculated for that seventh year. In order to get paid, performers therefore need to register with PPL and understand its mechanism.

63 SI 2016/221, supra n. 51, reg. 12(9a). 
Failure to do so results in not being paid and their revenue reverting to other members.

I note here that the database used to have all the contributor information visible to all the members, so that fans and colleagues could check on each other and help improve the database. This feature was removed in 2016. During the PPL workshop at my institution, we were told that PPL did this for privacy reasons. One of my interviewees argued that PPL had removed visibility of performer information in response to systematic technology-assisted searches by label services representing performers. ${ }^{64}$

The database is the core of a CMO's business: it holds the details of all of its members and their contributions to a work, in order to match moneys from licenses with payees. It is due to its complexity that PAMRA and AURA ultimately handed its administration over to PPL. According to current regulation, the system designed by PPL is to offer transparency to all, but has placed the responsibility for the appropriate registration of data in the hands of record companies. Performers, meanwhile, have responsibility only insofar as their details have not been appropriately registered by record companies. The implications of this system are discussed below.

\section{Performers on PPL}

In this section I draw on two different data sets: a set of 33 interviews I conducted with performers in London between 2014 and 2016, and a body of emails dating from March-October 2015. The interviews last each around one hour and are semi-structured around three broad topics: musical background, current projects and activities, and career satisfaction. I asked performers about institutional

64 Interview code [34-190110]. 
membership but not explicitly about their rights. Rather, I sought to understand the significance of performers' rights within performers' overall professional strategies. I have anonymised all of these interviews and identified them with a code. ${ }^{65}$

The emails were written by Les Hurdle. Hurdle is a bass player who worked as a session musician in the UK and the US from the mid-1960s onwards. Starting in 1996 and still going strong today, he then began emailing PPL to report irregularities, which has made him highly unpopular amongst its staff. With his permission, I had the opportunity of peeking through a six-month window of emails thanks to the expediency of my then research assistant, Adrian Aronsson-Storrier. Often short of legal insight and expressing impatience, the emails are useful in two ways: first, they regularly contain screenshots, and thus clear evidence, of problem points in the database; secondly, a systematic trawl of the emails offers a small number of distinct problem areas.

Problem areas include performer and contributor registration, the licensing of samples, the session fund, participation and voting at the Annual Performer Meeting and ring-fencing of non-distributed monies. I present here the most relevant examples for this discussion. On talking to Hurdle, I was drawn into another small network of performers who felt aggrieved by PPL's actions. Those performers who have been publicly vocal about PPL have not been anonymised.

\subsection{The Interviews}

Only a quarter of the 33 interviewees ( 24 per cent) said they were registered with

65 More details about this interview set can be found in Ananay Aguilar, "Distributed Ownership in Music: Between Authorship and Performance" (2018) 27(6) Social \& Legal Studies 776-798. 
PPL. Most of these musicians said they received little from PPL, often two-digit figures, which they compared to three- or four-digit figures from PRS (which may be due to the nature of the rights). Of the remaining 76 per cent, 42 per cent said they were registering, were disinterested or did not have time. Considering that their friends were not terribly impressed with PPL's revenue, registering with PPL was not a priority.

Those few who were successful at claiming monies from PPL were of the view that it became much easier once one understood how to use the database to one's advantage. Two PPL representatives I spoke to during events confirmed this, suggesting that registering with PPL required serious time investment that many musicians at the early stages of their careers could not afford. In contrast, those musicians who had either learned the tricks of the trade or could afford support staff were more likely to succeed in making claims. A representative of a music managers' organisation, interviewed in the context of another article, ${ }^{66}$ reported that many of the managers' clients spoke well of PPL. Like the successful few of my sample, this representative also highlighted that PPL was one of the best-functioning CMOs of its kind and the first choice of many performers eligible to register with CMOs of other jurisdictions. The implication here is that differences in perception may be based on differences in the resources of individual performers.

Problematically, the remaining 33 per cent had never heard of PPL. As I claimed in another article, ${ }^{67}$ this may be because performers are encouraged to think of their performances as a service, rather than as products to be owned. Hence, legal issues become secondary. Unfortunately, the institutions most

\footnotetext{
66 Aguilar, "We Want Artists to Be Fully and Fairly Paid for Their Work", supra n. 10.

67 Aguilar, supra n. 10, p. 12.
} 
heavily invested in performers' rights, the MU and PPL, do little to advertise these rights outside of their community of members.

\subsection{The Email Correspondence}

The emails provide a rich dataset of logged complaints and enquiries that were rarely acknowledged. The people copied into the emails changed from email to email but generally included musicians, who would add to Hurdle's comments and support questions with their own experience. Included were also one or two lawyers and academics, interested in the debate and able to provide background to some of the enquiries. The emails were addressed to PPL's CEO Peter Leathem, and former and current performer directors Gerald Newson and Crispin Hunt.

The following example provides evidence for the three main points I want to make here. These are the complexities surrounding the registration of i) performer line-up; ii) the making of claims by performers and iii) the session fund. The example shows how data registration is used strategically to the record companies' benefit, and so fits within Ewick and Selby's "with the law" narrative. Specifically, it shows how record companies use re-releases to register new entries without performer line-up. As described above, performers are denied registration of their performances on the PPL database, so have to wait to be registered by the record company they performed for or make a claim once the recording has been registered. Hurdle was understandably unhappy with this situation and kept sending emails drawing attention to irregularities in the registration.

One of these emails concerned two versions of the recording of Making your mind up by the band Bucks Fizz, shown in the body of the email through screenshots (Images 1 and 2). The recording bearing PPL ID 12294915 had been registered on $12^{\text {th }}$ June 2010, nearly 30 years after its recording in 1981. Sony BMG 
was the publisher and the long performer line-up included vocals and different types of instruments. In contrast, a remix of the same recording (PPL ID 669787764) added on $11^{\text {th }}$ June 2015, published by Sony BMG's successor Sony Music Entertainment lacks contributor information or recording date. On $12^{\text {th }}$ June 2015, the day after this controversial registration, Hurdle asked to raise this issue with Sony and received no response. ${ }^{68}$ A series of emails like this draws attention to inconsistencies in the database. The implications of this are discussed in the three sub-sections below.

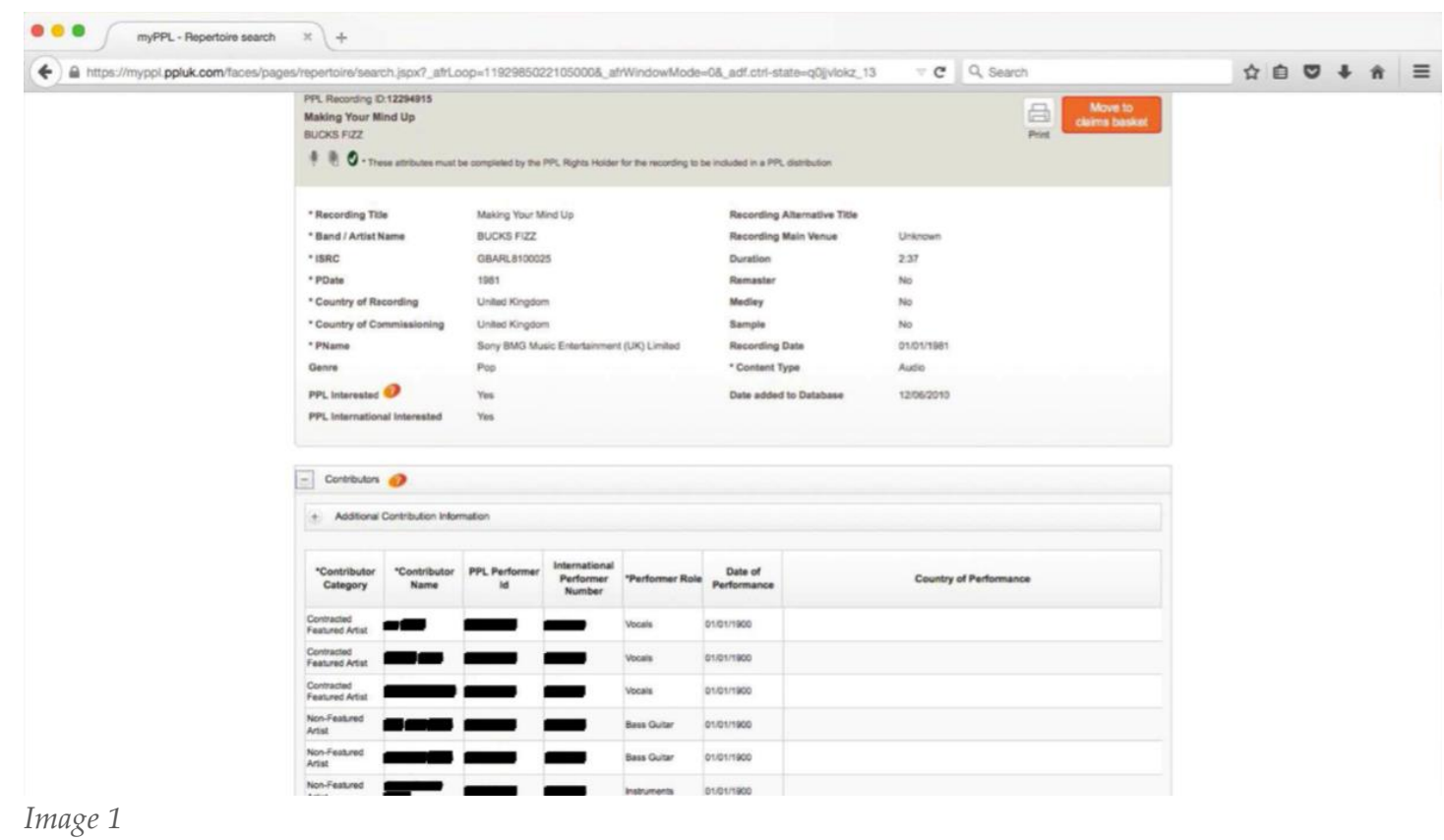

68 Les Hurdle, “[Bucks Fizz] Even SONY Can't Register Product Accurately” (6 December 2015). 


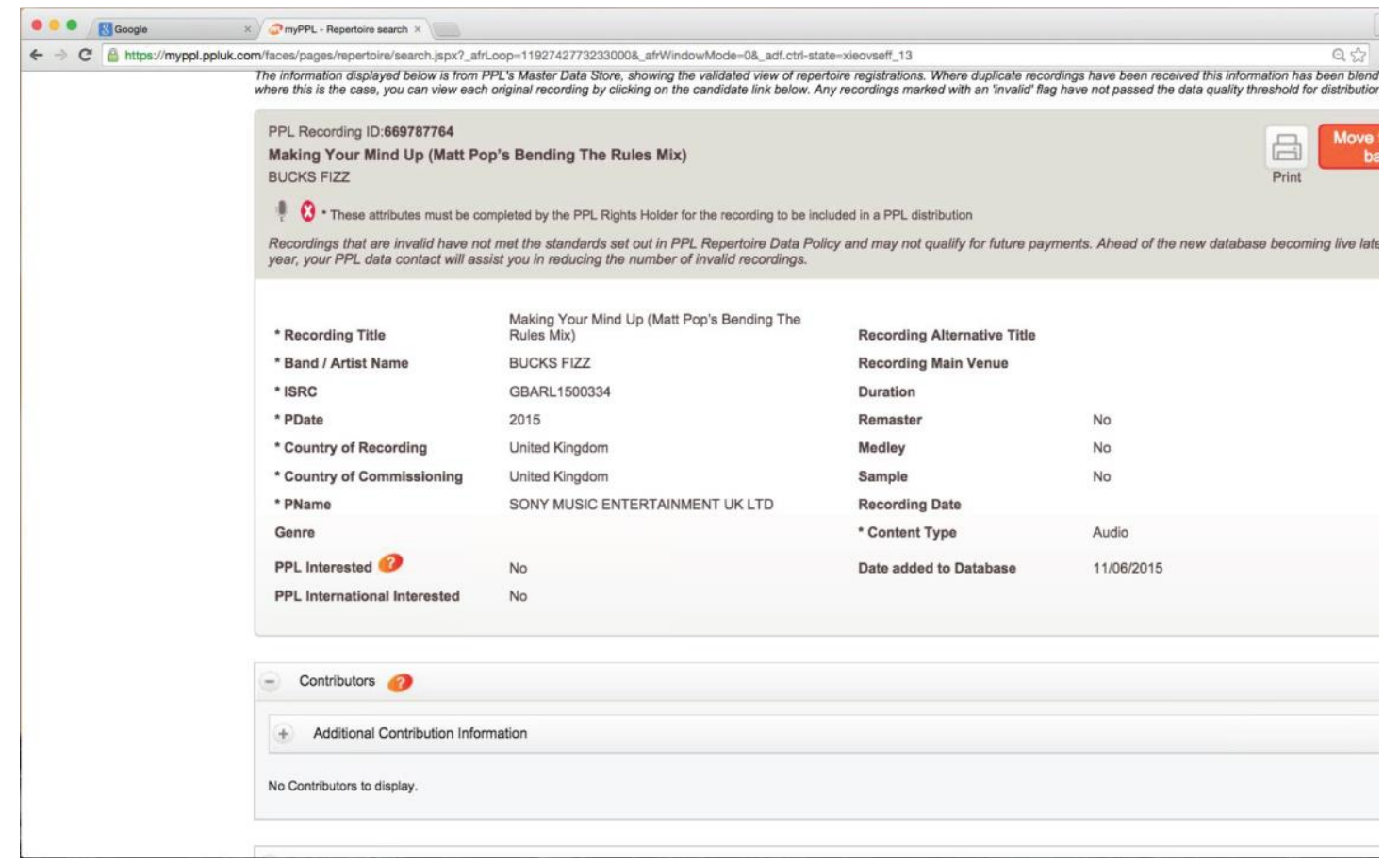

Image 2

\subsubsection{Performer Line-Up}

On 29 April 2015, Hurdle had drawn attention to a registration of the recording of Forty miles of bad road by Duane Eddy published in 1961, but added to the database on 28 April 2015 (54 years later) without recording date or performer line-up. Enraged by this incongruity, Hurdle asked why a registration would be made in 2015 when the recording dated from 1961. He added rhetorically: "What if an end user decides to ONLY [sic] use this version...?". ${ }^{69}$ One of the musicians copied in the email swiftly asked why PPL permitted registering recordings without performer information to start with.

CEO Peter Leathem felt compelled to respond on the same day: "We have actually explained on a number of occasions that the performer line up is not currently mandatory" ${ }^{70}$ Although current technology can detect incorrectly

69 Les Hurdle, “[GTRS] NOT Remastered but PD!" (29 April 2015).

70 Peter Leathem, “[GTRS] NOT Remastered but PD!” (29 April 2015). 
completed online forms - as is the case when in online forms one forgets to fill in a space and it is then highlighted in red-PPL is not interested in making use of it, nor, as Leathem implied, is PPL legally obliged to do so. Rather (and as explained in section 4.3), when these tracks are licensed, the record companies (in this last case Pickwick International) can claim all of the license revenue without having to share any of it with the recordings' performers.

On 18 August 2015, then PPL performer director Gerald Newson responded to another email that centred on the $20 \%$ session fund (to which I shall return). In this email he gave the good news of a policy change in performer registration: "Record Companies will in future not be paid unless they register and report to PPL full Line Up Complete". ${ }^{71}$

The new rules are enshrined in PPL Distribution Rules. ${ }^{72}$ These state that PPL may refrain from making distributions under a series of circumstances including the registration of "sufficient data". ${ }^{73}$ Rule 13.14 regarding the confirmation of repertoire, demands from record companies to notify PPL of any changes and refers to 13.13 to remind record companies that "PPL has the right to suspend any distributions to a Record Company until its confirmation has been received". The rules suggest that if a performer makes a claim or data is obviously suspect, then PPL has the right to withhold payments until the record company in question has addressed the issue. Although a positive development, performers are barred from policing this rule.

71 Gerald Newson, "RE: The 20\% French [Mess] to Come!" (18 August 2015); Tom Bateman, "Billie Jean Royalty Payments for Widow of Violinist" (29 January 2016) available at http://www.bbc.co.uk/news/entertainment-arts-35433224 (accessed 2 August 2018).

72 PPL, "PPL Code of Conduct for Members", supra n. 25, rules 13.13-14.

73 Ibid., rule 13.13(3). 


\subsubsection{Making a Claim}

As described above, the interface to the database has a "Claim" button for performers who wish to be added to the performer line-up. But making a claim can be a surprisingly complex task, as is evidenced by the well-documented story of Reginald Hill's widow Elisabeth. Elisabeth contacted me while I was advancing research for this article. In an interview with Tom Bateman for the BBC Radio 4 Today programme on 29 January 2016, Elisabeth explained the circumstances of her claim. ${ }^{74}$ Reginald had been second principal violinist for the London Symphony Orchestra when he decided in 1980 to move to Los Angeles to do session work. There he recorded for artists including Barbara Streisand, Frank Sinatra and Madonna. The story here concerns session work arranged by producer Quincy Jones for the Michael Jackson hit Billie Jean.

When Michael Jackson died, Elisabeth went on a quest to determine whether his husband had played in any of Jackson's productions. As Elisabeth explained on email to $\mathrm{me}^{75}$ she put together some paperwork (including American Federation of Musicians' [AFM] statements) making reference to Reginald's work on Thriller. PPL rejected this as proof. With the help of staff at the AFM and Sag-Aftra (a US union representing, amongst others, recording artists), Elisabeth then unearthed a contract between Jackson's record company and her late husband's union showing the violinist was paid US \$158 (£110) for the Billie Jean recording session. However, PPL rejected this too: PPL's working assumption was that Reginald Hill had indeed been in the studio but that his work had not necessarily made it onto the final mix of the recording. ${ }^{76}$ This was

\footnotetext{
74 "PPL Royalties - Widow Felt 'Less Than Human", BBC Radio 4 Today Programme (29 January 2016) available at https://www.youtube.com/watch?v=WeLsi6 JMEQ (accessed 2 August 2018); reported also as an article of the same date as Bateman, supra n. 74.

75 Elisabeth Hill, "My Experience with PPL" (2 February 2018).

76 Bateman, supra n. 71.
} 
eventually resolved with some help from the AFM and former colleagues of Reginald. The story demonstrates that PPL is likely to resist a performers' claim, however easy it appears on the database website to make one.

To some extent, PPL's suspicion is justified. As Hurdle explained in interview, the hiring of session musicians has taken many forms over the years:

Very often we would turn up on a recording date and there might have been some actual music and a title, but we wouldn't know who the artist was. Secondly, mostly in the disco era, we would find a piece of paper with some chords on it, but without a tune, and we'd be expected to make a rhythm track. We would record demos and the producer would put it on cassette tapes and send it to potential singers, so we wouldn't know what the tune was nor the artist and on what record we ended up in. ${ }^{77}$

As is still the case today, session musicians may be invited to record demos and be paid upfront recording fees without any link to a specific record [01M-150506]. This makes life difficult for performers who want to prove their contribution to a recording.

Unfortunately, the opposite is true as well. When performers' equitable remuneration rights were introduced, in the days of PAMRA, performers saw the potential of this system: since contribution was difficult to prove, performers could falsely claim contribution to highly successful tracks and demand payments [25-150602]. This is what Smith has termed the "four drummers syndrome", where several such tracks end up with more contributors than is feasible. ${ }^{78}$

77 Ananay Aguilar, Interview with Les Hurdle, "Interview with Les Hurdle" (1 October 2018).

78 Aguilar, Interview with Smith, supra n. 22. 
As I learned from the PPL instructor who came to my course, valid evidence can include the word of two other performers present on the day; pictures and other types of recorded information in magazines or fan-sites, and, in the case of orchestras, a letter by the record company's office confirming the musician's presence on the date claimed.

Returning to Elisabeth's case, on 20 February 2016, once she had begun to receive payments, she emailed CEO Peter Leathem to ask him to explain the value of the payments, the likelihood of her receiving retroactive payments and likely future payments both coming from the UK and the US. ${ }^{79}$ According to Elisabeth, Leathem responded on $29^{\text {th }}$ February. ${ }^{80}$ I reproduce one of his statements regarding international payments:

International payments will follow in due course as we follow through with the claiming process around the world. We have not claimed yet as we had not previously known that Reg had performed on Billie Jean. ${ }^{81}$

This statement is important because it contradicts CDPA s.182D transcribed above, whereby musicians are entitled to payments from record companies (not the users). CMOs license works and performances (in PPL's case the latter) and not the individual rights of individual contributors to a work or performance. A CMO should set a tariff for the combined individual licenses, collect this fee and then distribute it amongst the different contributors. In the UK, 50 per cent should go to the record companies and the rest be distributed amongst the performers. If an additional performer turns up, the tariff for the work is still the same. Assuming that PPL did claim licenses for Michael Jackson's Thriller, the

\footnotetext{
79 Hill, supra n. 75.

80 Hill, supra n. 75.

81 Hill, supra n. 75.
} 
tariff ought to be split amongst the other performers plus Reginald.

In addition, if my above description of PPL's operations holds true, PPL should pay Elisabeth for at least the last six years (taking from the nondistributable monies funds). But none of this is stated in quite as much detail in the current legal framework. Further clarification from PPL has been unforthcoming, so all she can do is wait and see. Might the alternative dispute mechanism outlined in the UK Copyright Licensing Regulations 2014 be in a position to force PPL to give more straightforward answers to her questions? She will have to weigh up any additional investment in bringing such claim with the time, effort, and possibly financial costs incurred already to simply proof her claim. Elisabeth thus continues to draw on informal sources of knowledge such as Reginald's colleagues, like many other claimants do in her case.

\subsubsection{The 20 per cent Session Fund}

The data registration of re-releases without performer line-up has also implications for the so-called 20 per cent session fund. This is a fund set up during the negotiations for the UK implementation of the Directive 2011/77/EU "on the term of protection of copyright and certain related rights". Drafted to extend the term of protection of copyright in sound recordings and performers' rights, the Term Extension Directive garnered support from the majority of UK industry players, including the MU, under the umbrella association UK Music, whilst attracting much resistance from academics and civil rights associations (for an analysis of the lobbying process preceding the implementation of the Directive see Vetulani-Cęgiel, 2015). When the Copyright and Duration of Rights in Performances Regulations 2013 was implemented, it included three "novel 
and innovative" measures designed to benefit performers ${ }^{82}$ the "session fund", 83 the "clean slate" provision, ${ }^{84}$ and the "use it or lose it" clause..$^{85}$

The session fund requires record companies to set aside, after 50 years of exploitation of their rights and until the end of the new copyright term of 70 years, 20 per cent of gross revenue from record sales and online distribution, including streaming. This percentage goes into a fund to help session musicians in their old age. At the time, this was considered a great success, as 20 per cent of gross revenue is more than any star has ever negotiated (typically around 15-20\% of net revenues). ${ }^{86}$ But soon, interested musicians noticed that record companies had started to re-master, re-mix or simply re-release records under different compilations, triggering a new copyright for each album. Record companies have control over the mainstream promotional networks and so they are able to direct audiences towards the recording with the new copyright. Older recordings fail to be distributed to retail shops and fall into oblivion in the huge archives of Spotify: they stop generating revenue.

During the time of my fieldwork, I had heard about this through word of mouth and in interviews, but the emails show evidence of these strategies through screen shots of PPL database searches such as the ones above. The examples show how, through limitations imposed on the database and on the performers' access to it, PPL controls what gets registered. Specifically, PPL

82 Department for Business, Innovation and Skills, Intellectual Property Office and James Younger, "Musicians Benefit from Extended Copyright Term for Sound Recordings GOV.UK" (Gov.uk, 11 January 2013) available at https://www.gov.uk/government/news/musicians-benefit-from-extended-copyright-termfor-sound-recordings (accessed 8 February 2018).

83 CDPA s.191HB.

84 Ibid.

85 CDPA s.191HA.

86 Donald Passman, All You Need to Know About the Music Business ( $8^{\text {th }}$ edn., New York: Viking, 2014), p. 89. 
makes sure that performers cannot police the database by checking who played in what track or song.

I thus turn to Ewick and Silbey's framework. As demonstrated above, PPL marshals several types of resources to protect the interests of record companies: social resources by training PPL representatives for their interface activities; financial resources by contributing to trade associations representing record companies' interests, such as BPI and IFPI ;7 legal resources when deploying their in-house lawyers to make sure they comply with current regulation, and technological resources by controlling the database software. Current regulation is flexible enough to protect PPL's interests at the expense of those of performers and, in particular, those of session musicians.

\section{What next?}

I have outlined PPL's history, attending to its involved relationship with the MU and performers in general. I have then drawn on current regulation to examine its operations and have finally turned to the perception of PPL of performers, with a focus on session musicians. I have argued that the status of performer members, in particular of session musicians, within PPL could be improved. I thus offer two sets of alternatives that might be available to strengthen the management of performers' legal rights.

\subsection{Tighten regulation at $\mathrm{CMO}$ level}

It is worth remembering that the MU tried, following the introduction of equitable remuneration rights in 1996, to set up its own CMO. This was a costly and largely unsuccessful experiment that forced the MU to cooperate with PPL.

87 PPL, "Strategic Report for the Year Ended 31 December 2016", supra n. 7, p. 22. 
It may be argued that with new technological advances, a renewed effort might be in reach of the MU, but to the best of my knowledge, no such project is currently being proposed. Such an effort, if unsuccessful, might further interfere with PPL-MU relations, which is undesirable. Under these circumstances, it is worth highlighting that PPL works reasonably well for most featured artists and arguably also for many session musicians under the rules provided by the current legal framework.

Assuming that performers and PPL will continue to cooperate, further regulation could be introduced to strengthen the position of performers and members of other CMOs. The following list requires more research but constitutes a start. An example to draw on could be the still timely MMC 1996 report, which gives clear guidelines on governance and management practice without the many conditions offered by the current Directive. In this area, a first step could be to introduce safeguards regarding membership status, so that members are not separated in different groups with different decision-making powers.

Regarding contributor registration, some assurances for the registration of full contributor line-up could be given. Rules 13.13-4 of the PPL Distribution Rules is a start, but guarantees of its enforcement need to be offered too. A requirement to include in contract details of the recording to which creators are contributing and to link new releases of recordings to older ones, could also help. Last but not least, a more strategic provision regarding non-distributed monies might discourage deliberate non-distribution. So, for instance, non-distributed monies (and their interests) could go into an independently managed retirement fund.

Regarding the alternative dispute mechanism, a much stronger, harmonised mechanism could be offered in order to level the playing field between individual creators and their powerful CMOs. Some indication of the 
direction this mechanism could take has been outlined in amendments to the current copyright reform process responding to the European Commission's 2016 proposal for copyright in the digital single market. 88 Two of the European Parliament's committees proposed to level the playing field when using an alternative dispute mechanism, such as third-party representation and anonymity.$^{89}$ One committee also suggested to make the procedure affordable..$^{90}$

Finally, Hviid, Schroff and Street have also promoted a tighter link between copyright and licensing regulation so that licensing systems are consistent within and across rights. ${ }^{91}$ As the authors put it, "the failure of licensing practices to change quickly enough could actually harm the aim of copyright as a whole". ${ }^{92}$

\subsection{Introduce Further Competition}

An alternative to treating CMOs as natural monopolies and tightening regulation on their internal processes, is to introduce competition into the licensing market

88 European Commission, Proposal for a Directive of the European Parliament and of the Council on copyright in the Digital Single Market 2016 [2016/0280 (COD)].

89 Zdzisław Krasnodębski, "OPINION of the Committee on Industry, Research and Energy for the Committee on Legal Affairs on the Proposal for a Directive of the European Parliament and of the Council on Copyright in the Digital Single Market (COM(2016)0593-C80383/2016-2016/0280(COD))" (8 January 2017), available at http://www.europarl.europa.eu/sides/getDoc.do?pubRef=$\% 2 \mathrm{f} \% 2 \mathrm{fEP} \% 2 \mathrm{f} \% 2 \mathrm{fNONSGML} \% 2 \mathrm{bCOMPARL} \% 2 \mathrm{bPE}-$ 592.363\%2b03\%2bDOC\%2bPDF\%2bV0\%2f\%2fEN (accessed 31 January 2018).

90 Marc Joulaud, "OPINION of the Committee on Culture and Education for the Committee on Legal Affairs on the Proposal for a Directive of the European Parliament and of the Council on Copyright in the Digital Single Market (COM(2016)0593-C8-0383/2016 2016/0280(COD))" (9 April 2017), available at http://www.europarl.europa.eu/sides/getDoc.do?pubRef=$\% 2 \mathrm{f} \% 2 \mathrm{fEP} \% 2 \mathrm{f} \% 2 \mathrm{fNONSGML} \% 2 \mathrm{bCOMPARL} \% 2 \mathrm{bPE}-$ 595.591\%2b03\%2bDOC\%2bPDF\%2bV0\%2f\%2fEN (accessed 31 January 2018), art. 16(1a) or amd. 96.

91 Hviid, Schroff and Street, supra n. 4, paras. 33-34 and 49.

92 Ibid., para. 34 . 
and give creators choice of CMO. This was exactly the rationale behind the European CRM Directive. As outlined above, the Directive consists of two parts, one focussing on the internal structure and processes of CMOs and one on a new licensing configuration for musical works in the digital age. According to Hviid, Schroff and Street, the focused nature of the second section effectively created a system with two parallel licensing regimes: one analogue, the other digital. ${ }^{93}$ As the authors have identified, this offers a historical opportunity to compare both regimes. Up until now, only record companies (or digital rights agencies on behalf of independent record companies) had managed their own licenses for their making available rights. The changes introduced by the CRM Directive effectively mean that authors (and through them, publishers too) are placed in the same position as record companies. This might benefit publishers but could have undesirable effects for authors and, assuming this trend extends further, for performers as well.

For most of the CMOs' life, rightsholders and users in most wealthy economies of the world (with the notable exception of the US) had broadly agreed that having one $\mathrm{CMO}$ for each particular set of rights was preferable over a competitive market. ${ }^{94}$ Reasons for this are many; I outline a few here.

In a fragmented market with competing CMOs, users have to go through the costly process of searching for the right licensors and negotiate with them different repertoires. ${ }^{95}$ In order to bypass this complexity, users are tempted to license music from the CMOs with the largest or most popular repertoire, privileging specific repertoires at the expense of alternative ones. ${ }^{96}$ This has led to price differentiation between repertoires, driven not so much by musical

\footnotetext{
93 Ibid., paras. 33-4 and 49.

94 Monopolies and Mergers Commission, supra n. 32, para 2.111; UNESCO, supra n. 41.

95 Hviid, Schroff and Street, supra n. 4.

96 Street, Laing and Schroff, supra n. 6, 15.
} 
quality or diversity, but by a CMO's size of repertoire, relative power and influence. Direct negotiations between the major record companies and DSPs such as Spotify already illustrate this. ${ }^{97}$ In the long run, this is likely to negatively affect independent musicians, who would find their bargaining power weakened..$^{98}$ This lowering of their bargaining power would then reflect on the price of their licenses; as Harris put it in interview: "it would be a race to the bottom". ${ }^{99}$

From the CMOs' perspective, their work's fragmentation leads to inefficiencies. These include, firstly, inefficiencies in the construction and maintenance of the databases from which CMOs draw their value. ${ }^{100}$ In an analogue world, inefficiencies occur also in the collection of licence fees in sparsely populated locations, where representatives for several CMOs need to create and run separate collection mechanisms. ${ }^{101}$

According to the European Commission, ${ }^{102}$ this needn't be the case in the digital age. Despite this, CMOs licensing different rights not only continue to operate as single monopolies, but still come together to decrease inefficiencies in this area. So, for instance, in the UK, as of 2017, PRS for Music (in charge of music authors' and publishers' performing and mechanical rights) joined forces with PPL (managing record companies' and performers' recording rights) to offer a joint public performance licence at the point of collection. ${ }^{103}$ More

97 See for instance the leaked Sony Music, "Sony Music - Spotify USA Inc Digital Audio/Video Distribution Agreement".

98 Dietz, supra n. 2; Graber, supra n. 2.

99 Aguilar, Interview with Harris, supra n. 22.

100 Katz, "The Potential Demise Of Another Natural Monopoly", supra n. 3.

101 Monopolies and Mergers Commission, supra n. 32, para 2.111.

102 Katz, "The Potential Demise Of Another Natural Monopoly", supra n. 3.

103 PRS for Music, "PRS and PPL Confirm Plan to Create Joint Venture" (PRS for Music, 2 February 2016) available at https://www.prsformusic.com:443/press/2016/prs-for-music-andppl-confirm-plan-to-create-new-joint-venture-for-public-performance-licensing (accessed 8 February 2018); PRS for Music, "Suzanne Smith Named Managing Director of Joint Venture" 
problematically, at a regional level and to address the complexities faced by users, CMOs have come together to create licensing hubs. However, these do not represent individual members but act as an administrative stopgap to deal with the problems of fragmentation encouraged by the Directive.

Hviid, Schroff and Street thus defend the advantages of the analogue regime under a monopoly: simplicity for users faced with a one-stop-shop; clarity over which CMOs cover which rights and repertoires; transparency regarding licensing tariffs, and greater musical diversity through cross-subsidies of new and minority cultural expressions by established mainstream acts. In contrast, in the competition fostered within the digital regime, the negotiating cost is transferred to the user (who must do the research and leg-work to pay everyone) or indeed the creator and rights holder (who have to take the music to the user) and price is driven down as collective bargaining power disappears. The beneficiaries of this system would be the most successful featured artists and large rights holders (i.e. publishers and record companies), who can afford the cost of hiring someone to manage the licensing of their rights. However, this has the consequence of attacking cross-subsidies, lowering the bargaining position of the majority of artists and reducing cultural diversity. Here again, a minority of highly successful featured artists are privileged over a large majority of up-andcoming and session artists.

Much talked about technologies such as blockchain technology would introduce an extreme form of fragmentation, where all collective bargaining power would be removed. As I was told informally by one of the leaders in this area, this is exactly the point. Thus, for them and other up-and-coming musicians, using these technologies or registering with small independent licensing 
organisations might be perceived as advantageous when compared with registering with behemoths such as PPL and the baggage they bring with them.

\section{Conclusions}

In summary, I have introduced the record company-owned PPL from its beginnings, focussing on its involved relationship with the MU and performers in general. Over nearly a hundred years, mutual needs have combined with external circumstances, altering the different actors' relative bargaining power. Drawing on interviews with Harris and Smith, I have shown how PPL has, over the last decade, increased the representation of performers on its board. While these are overall positive developments, I have argued that this is mostly symbolic. PPL continues to be owned by record companies, who are legally the only "members" and the only ones entitled to attend the annual general meeting.

I have then moved on to current regulation controlling the work of CMOs. I have indicated that regulation is necessary to offer minimum standards to members and users. Current regulation is too weak and requires assurances to members regarding quantities of money due. Analysis of PPL's interface material (the website, workshops and database), interviews with performers and PPLperformer correspondence suggest that PPL works "with the law" to protect record companies' interests. As I have sought to demonstrate, non-distributed payments are re-distributed to successfully registered members, which are more likely to be record companies and a minority of featured artists. From PPL's perspective, the complexities added to the performers' experience of using the database are therefore justified. Although far from ideal, PPL is backed by the currently existing legal framework.

Under these circumstances and assuming that setting up a performerowned CMO is unrealistic at this time, in the last section I examined two sets of 
alternatives: further tightening the regulation on $\mathrm{CMO}^{\prime}$ s internal structures and processes or introducing competition to force CMOs to improve their practices. Commentators oppose competition arguing that it ultimately impoverishes cultural diversity. However, regulators resist further tightening of CMO's internal structures and processes and, at least in Europe, have opted for introducing competition into the sector. In this environment it is understandable that musicians seek to take the management of their licenses into their own hands, for instance by exploring blockchain technologies, even if this leads to an extreme form of fragmentation.

In this scenario, addressing the performers' extended ignorance about performers' rights identified above is fundamental to moving this debate in the right direction. Performance schools and bodies such as the MU must include the teaching of performers' rights within the performer curriculum. Only by educating musicians about their rights, performers will make informed decisions, take ownership of the management of their licenses, and leverage their large audiences to campaign for regulation that suits their interests and earns the public's legitimacy that copyright so urgently needs. 